\title{
Job Satisfaction of Social Service Workers in Penitentiary Institutions in Albania
}

\author{
Enida Kume \\ "Alexander Moisiu" University, Durrës, Albania \\ enidak@hotmail.it
}

\begin{abstract}
This study analyzes job satisfaction of Social Service Workers of Penitentiary Institutions in Albania. The overall job satisfaction of Social Service Workers of Penitentiary Institutions in Albania is associated with 12 variables. These variables are the most important among all the 24 variables that taken in consideration in this study. If these factors are considered carefully, then there will be a positive overall satisfaction of Social Service Workers of Penitentiary Institutions. This study gives a message to the employers of Penitentiary Institutions that if they want to improve job satisfaction of Social Service Workers then they have to consider the above 12 variables: recognition for good work, adequate remuneration for work, feel proud of job, satisfaction from non-financial rewards, motivated to work, job is meaningful, available opportunities for promotion, exchange of ideas between superior and subordinate, job evaluated reward, relationship -colleagues, training program regularly and satisfied with available opportunities. This study covers a wide range of independent variables that significantly influences job satisfaction of Social Service Workers of Penitentiary Institutions; however, referring to the limited number of data, this study fails to bring a complete and exhaustive evaluation picture on job satisfaction of social workers of Penitentiary Institutions in Albania.
\end{abstract}

Keywords: Job satisfaction, social service workers, penitentiary institution

\section{Introduction}

Job satisfaction has been defined as an emotional reaction to the work situation (Ilham, 2009, Locke, 1969, 1976). Perhaps the best-known definition of job satisfaction is Locke's contention that "job satisfaction is a pleasurable or positive emotional state resulting from an appraisal of one's job or job experiences" (Locke, 1976). Rahma, M.M et al. (2012) underline that "The degree of satisfaction is determined by the ratio outcomes against the desire of employees from their respective jobs. By law of nature as we have more, we want more, hence the level of satisfaction remain less. Job satisfaction is dynamic, as it can go as quickly as it comes. It is positive emotional state that occurs when a person's job seems to fulfill important values, provided these values are compatible with one's needs"

The penitentiary Institutions in Albania are considered by social service employees as a good opportunity to exercise their profession and as a job that is in line with their expectations (Kume, E. 2013). Given the target groups (prisoners) to whom this service is offered, it is naturally that "...social service workers must often deal with intense emotional issues and are frequently confronted with disturbing situations (Bernal, J.G., et al. 2005, Zaimi, et al. 2013).

The purpose of this study is the evaluation the job satisfaction level and identification of factors (variables) important for social service employee's job satisfaction in order to plan and carry out the necessary intervention in order to increase the effectiveness of this service in penitentiary Institutions in Albania.

The objectives of the study are: (i) to identify the most important factors of job satisfaction, (ii).to identify the level of satisfaction of social service specialist in penitentiary Institutions and (iii) to evaluate the correlation between job satisfaction and factors of job satisfaction

\section{Methodology}

\section{Sample Design}


The targets of this study are 36 social service specialists who work in 23 penitentiary institutions. A structured questionnaire was developed using job satisfaction forces to which the respondents was asked to react using a seven step Bi-polar scale ranging from strongly disagree (1) to strongly agree (7).

At the end of the questions, a final question was added: "overall I am satisfied about my job". This question was intended to measure the respondent's reaction to the job satisfaction in a scale. Bipolar scale has been selected because of its widespread appropriateness of measuring attitude (Rahma, M.M et al. 2012)

The demographic compositions of the respondents are shown in Figure no.1
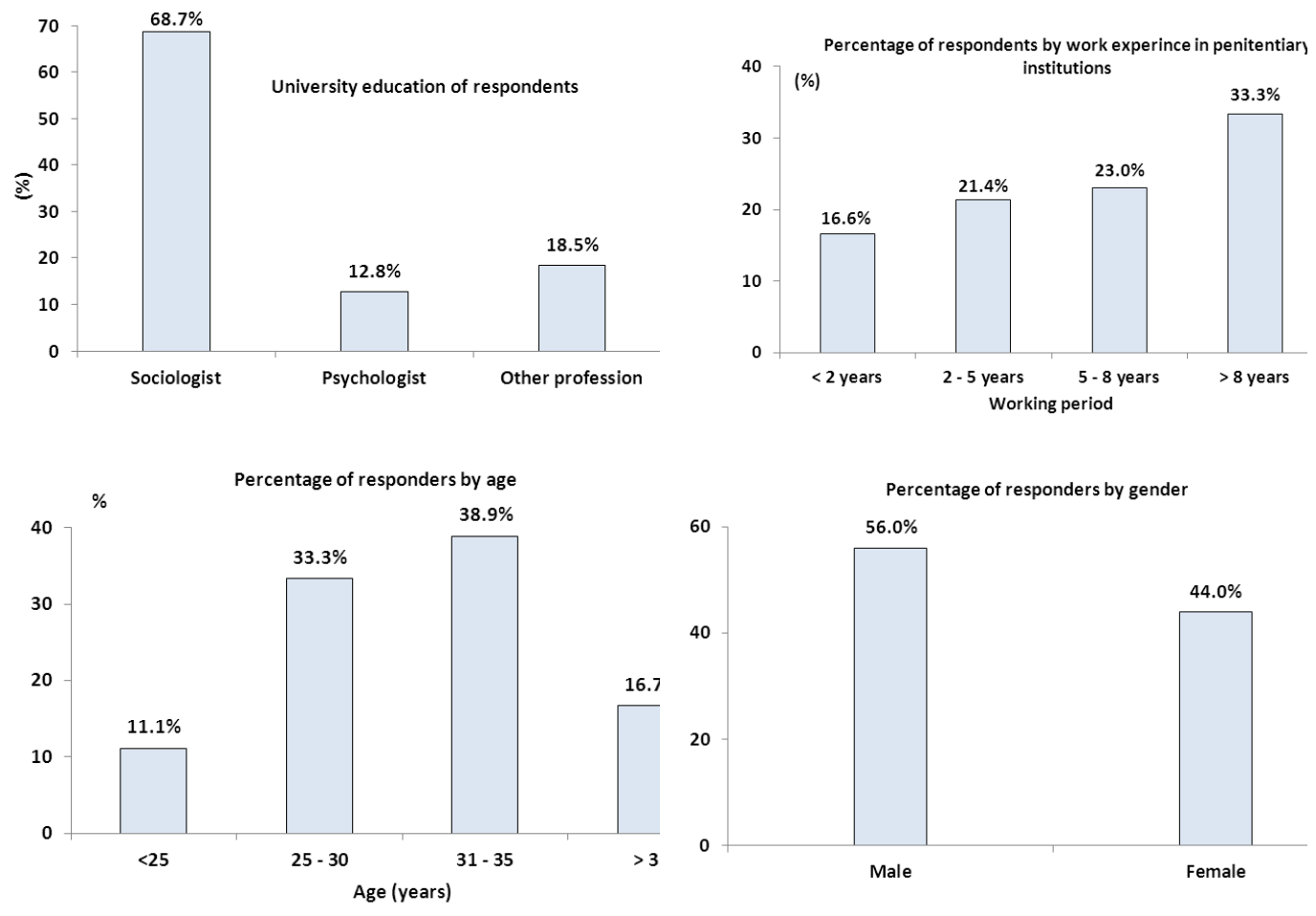

Figure no.1 Demographic characteristics of respondents

\section{Methods}

SPSS 17.0 and Excel have been used to process and analyze the data. Dependent and independent variables are analyzed by using correlation and linear regression. Different statistical tools like ANOVA, T-test have been used to assess and interpret data. ANOVA has been used to analyze the relationship of job satisfaction factors with overall satisfaction of employees. T-tests have been performed to test the statistical significance of the parameters at $5 \%$ level of significance.

Statistical parameters like mean, standard deviations will be estimated. In order to evaluate and estimate the significance level among dependent and independent variables, the variables are further analyzed with the help of regression model. Overall job satisfaction is the dependent variable and adequate remuneration for work, job is meaningful, salary increases on performance, satisfaction from non-financial rewards, job evaluated reward, available opportunities for promotion, satisfied with available opportunities, feel proud of job, training program regularly, use skill, experience and qualification, top management support, satisfied environment, recognition for good work, motivated to work, flexibility working hours, like job, job meaningful, relationship-colleagues, collective work, team work, colleagues help, supervisors care, trust between superior and subordinates and exchange of ideas between superior and subordinates are independent variables 
The regression model is as follows:

OJS $=\alpha+\beta_{1} X_{1}+\beta_{2} X_{2}+\beta_{3} X_{3}+\beta_{4} X_{4}+\beta_{5} X_{5}+\beta_{6} X_{6}+\beta_{7} X_{7}+\beta_{8} X_{8}+\beta_{9} X_{9}+\beta_{10} X_{10}+\beta_{11} X_{11}+\beta_{12} X_{12}+\beta_{13} X_{13}+\beta_{14} X_{14}+\beta_{15} X_{15}+\beta_{16} X_{16}+$ $\beta_{17} X_{17}+\beta_{18} X_{18}+\beta_{19} X_{19}+\beta_{20} X_{20}+\beta_{21} X_{21}+\beta_{22} X_{22}+\beta_{23} X_{23}+\beta_{24} X_{24}+\varepsilon_{t}$

Where:

OJS-Overall Job Satisfaction

$\mathrm{X}_{1}$ - Adequate remuneration for work

$\mathrm{X}_{2}-\mathrm{Job}$ is meaningful

$X_{3}$ - Salary increases on performance

$X_{4}$ - Satisfaction from non-financial rewards

$X_{5}$ - Job evaluated reward

$\mathrm{X}_{6}$ - Available opportunities for promotion

$X_{7-}$ Satisfied with available opportunities

$\mathrm{X}_{8}$ - Feel proud of job

$\mathrm{X}_{9}$ - Training program regularly

$X_{10}$ - Use skill, experience and qualification

$X_{11}$ - Top management support

$X_{12-}$ Satisfied environment

$\mathrm{X}_{13}$ - Recognition for good work
$X_{14-}$ Motivated to work

$X_{15}$ - Flexibility working hours

$\mathrm{X}_{16-\text { Like job }}$

$X_{17-}$ Job meaningful

$\mathrm{X}_{18}$ - Relationship -colleagues

$X_{19-}$ Collective work

$\mathrm{X}_{20}$ - Team work

$X_{21}$ - Colleagues help

$\mathrm{X}_{22}$ - Supervisors care

$\mathrm{X}_{23}$ - Trust between superior and subordinates

$X_{24-}$ Exchange of ideas between superior and subordinates

$\varepsilon_{\mathrm{t}}$ - Error Term

and $\alpha$ is a constant and $\beta_{1}, \beta_{2}, \beta_{3}, \beta_{4}, \beta_{5}, \beta_{6}, \beta_{7}, \beta_{8}, \beta_{9}, \beta_{10}, \beta_{11}, \beta_{12}, \beta_{13}, \beta_{14}, \beta_{15}, \beta_{16}, \beta_{17}, \beta_{18}, \beta_{19}, \beta_{20}, \beta_{21}, \beta_{22}, \beta_{23}, \beta_{24}$ are coefficients to estimate.

\section{Results and discussion}

The mean value and standard deviation of variables are showed in Table no.1. The mean value of all factors, except Flexibility working hours, Team work and Colleagues help, is more than 5.0 which is between the neutral and agree in the scale showing the average employees perception about job satisfaction.

Table no. 1 Descriptive Statistics

\begin{tabular}{|l|l|l|l|l|l|}
\hline Variable & Main & $\begin{array}{l}\text { Standard } \\
\text { deviation }\end{array}$ & Variable & Main & $\begin{array}{l}\text { Standard } \\
\text { deviation }\end{array}$ \\
\hline Adequate remuneration for work & 5.06 & 0.721 & Recognition for good work & 5.06 & 0.634 \\
\hline Job is meaningful & 6.13 & 0.824 & Motivated to work & 5.32 & 0.891 \\
\hline Salary increases on performance & 5.02 & 0.703 & Flexibility working hours & 4.61 & 0.637 \\
\hline Satisfaction from non-financial rewards & 6.09 & 0.986 & Like job & 5.36 & 0.843 \\
\hline Job evaluated reward & 5.72 & 0.712 & Job meaningful & 5.82 & 0.784 \\
\hline
\end{tabular}




\begin{tabular}{|l|l|l|l|l|l|}
\hline Available opportunities for promotion & 5.42 & 0.783 & Relationship -colleagues & 5.21 & 0.782 \\
\hline Satisfied with available opportunities & 5.31 & 0.923 & Collective work & 5.03 & 0.789 \\
\hline Feel proud of job & 6.04 & 1.003 & Team work & 4.81 & 0.853 \\
\hline Training program regularly & 5.21 & 0.754 & Colleagues help & 4.16 & 0.609 \\
\hline Use skill, experience and qualification & 6.02 & 0.762 & Supervisors care & 5.10 & 0.712 \\
\hline Top management support & 5.21 & 0.759 & $\begin{array}{l}\text { Trust between superior and } \\
\text { subordinates }\end{array}$ & 5.03 & 0.735 \\
\hline Satisfied environment & 5.03 & 0.692 & $\begin{array}{l}\text { Exchange of ideas between } \\
\text { superior and subordinate }\end{array}$ & 5.13 & 0.789 \\
\hline Overall Job Satisfaction & 5.23 & 0.897 & & & \\
\hline
\end{tabular}

From Table no.2, it is seen that there is a significant correlation between dependent variable and independent variables. At $5 \%$ level of significance the correlation is $88.2 \%$. Here, adjusted R square is 0.722 which tells us about $72.2 \%$ variation of dependent variable is explained by independent variables included in regression model.

Table. No. 2 Model Summary

\begin{tabular}{|l|l|l|l|l|}
\hline Model & $R$ & R Square & Adjusted R Square & Std. Error of the Estimate \\
\hline 1 & $.8823^{a}$ & .779 & .722 & 0.394 \\
\hline
\end{tabular}

Table no. 3 , shows that the regression equation is explaining a statistically significant portion of the variability in the dependent variable from variability in the independent variables. Therefore we can conclude that it accurately explains that the overall job satisfaction of the social service specialists who work in penitentiary institutions depends on the factors that have entered in the model.

Table no.3. ANOVA ${ }^{a}$

\begin{tabular}{|l|l|l|l|l|l|l|}
\hline \multicolumn{2}{|l|}{ Model } & $\begin{array}{l}\text { Sum of } \\
\text { Squares }\end{array}$ & df & Mean Square & F & Sig. \\
\hline \multirow{4}{*}{1} & Regression & 342.86 & 24 & 54.14 & 15.60 & $.00^{\text {b }}$ \\
\cline { 2 - 8 } & Residual & 107.52 & 11 & 3.47 & & \\
\cline { 2 - 7 } & Total & 450.38 & 35 & & & \\
\hline
\end{tabular}


b. Predictors: (Constant), adequate remuneration for work, job is meaningful, salary increases on performance, satisfaction from non-financial rewards, job evaluated reward, available opportunities for promotion, satisfied with available opportunities, feel proud of job, training program regularly, use skill, experience and qualification, top management support, satisfied environment, recognition for good work, motivated to work, flexibility working hours, like job, job meaningful, relationship-colleagues, collective work, team work, colleagues help, supervisors care, trust between superior and subordinates, exchange of ideas between superior and subordinates

Table no.4 shows the coefficients between dependent and independent variables. According to significant values of the coefficients for adequate remuneration for work, job is meaningful, salary increases on performance, satisfaction from nonfinancial rewards, satisfaction from non-financial rewards, job evaluated reward, available opportunities for promotion, training program regularly, recognition for good work, motivated to work, flexibility working hours, job meaningful are statistically significant $(p<0.00)$ and satisfied with available opportunities, feel proud of job, relationship-colleagues are statistically significant $(p<0.05)$. The coefficients for other independent variables are not statistically significant which implies that these factors have some impact on overall job satisfaction but these are not considerable.

Referring to the values of standardized coefficients that correspond to the variables that have statistical significant effect on dependent variable, overall job satisfaction, in Table no 5 , are chronologically ranked the variables that should be taken in consideration by the decision making body in drafting policies that want to increase job satisfaction level for social service specialist in penitentiary Institutions.

Table no. 4 Coefficients $^{a}$

\begin{tabular}{|c|c|c|c|c|c|c|}
\hline \multirow{2}{*}{\multicolumn{2}{|c|}{ Model }} & \multicolumn{2}{|c|}{$\begin{array}{l}\text { Unstandardized } \\
\text { Coefficients }\end{array}$} & \multirow{2}{*}{$\begin{array}{l}\begin{array}{l}\text { Standardized } \\
\text { Coefficients }\end{array} \\
\beta\end{array}$} & \multirow{2}{*}{$t$} & \multirow{2}{*}{ Sig. } \\
\hline & & \multirow{2}{*}{$\begin{array}{l}\beta \\
2.346\end{array}$} & \multirow{2}{*}{$\begin{array}{l}\begin{array}{l}\text { Std. } \\
\text { Error }\end{array} \\
0.561\end{array}$} & & & \\
\hline \multirow{14}{*}{1} & Constant & & & & 2.32 & 0.75 \\
\hline & Adequate remuneration for work & 0.468 & 0.231 & 0.387 & 3.76 & 0.00 \\
\hline & Job is meaningful & 0.521 & 0.268 & 0.294 & 3.98 & 0.00 \\
\hline & Salary increases on performance & 0.219 & 0.318 & 0.128 & 3.07 & 0.00 \\
\hline & Satisfaction from non-financial rewards & 0.326 & 0.056 & 0.307 & 4.02 & 0.00 \\
\hline & Job evaluated reward & 0.189 & 0.082 & 0.256 & 4.12 & 0.00 \\
\hline & Available opportunities for promotion & 0.321 & 0.125 & 0.287 & 3.08 & 0.00 \\
\hline & Satisfied with available opportunities & 0.156 & 0.025 & 0.203 & 2.75 & 0.05 \\
\hline & Feel proud of job & 0.507 & 0.089 & 0.321 & 2.98 & 0.05 \\
\hline & Training program regularly & 0.329 & 0.120 & 0.237 & 3.67 & 0.00 \\
\hline & Use skill, experience and qualification & -0.221 & 0.107 & -0.241 & -1.11 & 0.62 \\
\hline & Top management support & 0.142 & 0.112 & 0.067 & 1.67 & 0.09 \\
\hline & Satisfied environment & 0.068 & 0.321 & 0.088 & 1.06 & 0.62 \\
\hline & Recognition for good work & 0.367 & 0.054 & 0.406 & 3.69 & 0.00 \\
\hline
\end{tabular}




\begin{tabular}{|l|l|l|l|l|l|l|}
\hline Motivated to work & 0.293 & 0.217 & 0.302 & 3.05 & 0.00 \\
\hline Flexibility working hours & -0.324 & 0.142 & -0.289 & -3.12 & 0.00 \\
\hline Like job & 0.387 & 0.121 & 0.098 & -1.68 & 0.10 \\
\hline Job meaningful & 0.309 & 0.120 & 0.152 & 3.17 & 0.00 \\
\hline Relationship -colleagues & 0.341 & 0.122 & 0.241 & 2.06 & 0.05 \\
\hline Collective work & -0.027 & 0.203 & -0.067 & -1.04 & 0.62 \\
\hline Team work & -0.257 & 0.065 & -0.185 & -1.07 & 0.62 \\
\hline Colleagues help & 0.067 & 0.103 & 0.024 & 2.19 & 0.05 \\
\hline $\begin{array}{l}\text { Supervisors care } \\
\text { Trust between superior and subordinates }\end{array}$ & -0.127 & 0.111 & -0.204 & -1.87 & 0.09 \\
\hline $\begin{array}{l}\text { Exchange of ideas between superior and } \\
\text { subordinate }\end{array}$ & -0.357 & 0.098 & 0.276 & -1.90 & 0.08 \\
\hline a. Dependent Variable: Overall Job Satisfaction & & & -0.183 & 0.15 & 0.00 \\
\hline
\end{tabular}

Table no. 5. Rank order of variables

\begin{tabular}{|l|l|l|}
\hline Variables & Value & $\begin{array}{l}\text { Rank order on the basis of } \\
\text { significance }\end{array}$ \\
\hline Recognition for good work & 0.406 & 1 \\
\hline Adequate remuneration for work & 0.387 & 2 \\
\hline Feel proud of job & 0.321 & 3 \\
\hline Satisfaction from non-financial rewards & 0.307 & 4 \\
\hline Motivated to work & 0.302 & 5 \\
\hline Job is meaningful & 0.294 & 6 \\
\hline Available opportunities for promotion & 0.287 & 7 \\
\hline Exchange of ideas between superior and subordinate & 0.276 & 8 \\
\hline Job evaluated reward & 0.256 & 9 \\
\hline Relationship -colleagues & 0.241 & 10 \\
\hline Training program regularly & 0.237 & 11 \\
\hline Satisfied with available opportunities & 0.203 & 12 \\
\hline
\end{tabular}

\section{Conclusions}

This study analyzes job satisfaction of Social Service Workers of Penitentiary Institutions in Albania.

The overall job satisfaction of Social Service Workers of Penitentiary Institutions in Albania is associated with 12 variables. These variables are the most important among all the 24 variables that taken in consideration in this study. If these factors are considered carefully, then there will be a positive overall satisfaction of Social Service Workers of Penitentiary 
Institutions. This study gives a message to the employers of Penitentiary Institutions that if they want to improve job satisfaction of Social Service Workers then they have to consider the above 12 variables: recognition for good work, adequate remuneration for work, feel proud of job, satisfaction from non-financial rewards, motivated to work, job is meaningful, available opportunities for promotion, exchange of ideas between superior and subordinate, job evaluated reward, relationship -colleagues, training program regularly and satisfied with available opportunities

This study covers a wide range of independent variables that significantly influences job satisfaction of Social Service Workers of Penitentiary Institutions; however, referring to the limited number of data, this study fails to bring a complete and exhaustive evaluation picture on job satisfaction of social workers of Penitentiary Institutions in Albania.

\section{Leterature}

Bernal, J.G., Castel A.G., Navarro, M.M., and Torres P.R., (2005), "Job satisfaction: empirical evidence of gender differences", Women in Management Review, vol. 20, No. 4.

Ilham Dahir Sheikh Mohamoud (2009). The role of work motivation on employee performance. Master's thesis. Universiti Utara Malaysia, Kedah.

Kume, E. 2013 "Punonjesi social ne sistemin e drejtesise dhe arsimin parauniversitar. Master` thesis. University of Tirana, Albania

Lise M. Saari, Timothy A. Judge (2004) Human Resource Management, Vol. 43, No. 4, Pp. 395-407

Locke, E.A., (1969), "What is job satisfaction", Organizational Behavior and Human Performance, Vol. 4, Iss. 4, pp. 309336.

Locke, E. A. (1976). The nature and causes of job satisfaction. In M. D. Dunnette (Ed.), Handbook of industrial and organizational psychology (pp. 1297-1349). Chicago: Rand McNally.

Lund, D.B. (2003), "Organizational culture and job satisfaction”, Journal of Business and Industrial Marketing, Vol. 18, No 3, pp. 219-236.

Remus llies, Timothy A. Judge (2004) An experience-sampling measure of job satisfaction and its relationships with affectivity, mood at work, job beliefs, and general job satisfaction. European Journal Of Work And Organizational Psychology, 13 (3), 367-389

Rahman, M.M. Das Gupta, A., Moudud-UI-Huq, S. (2012) Job Satisfaction of Female Employees in Financial Institutions of Bangladesh: A Study on Selected Private Commercial Banks in Chittagong. Global Journal of Management and Business Research. Volume 12 Issue 14 Version 1.0

Zaim, H., Zaim, S. 2013 Measuring employee satisfaction in small and medium sized enterprises. First International Conference on Management and Economics, "epoka" University, Tirana, Albania 